Vol. 10 (2001): 197-208.

\title{
Effect of annually repeated undersowing on cereal grain yields
}

\author{
Hannu Känkänen \\ MTT Agrifood Research Finland, Plant Production Research, FIN-31600 Jokioinen, Finland, \\ e-mail: hannu.kankanen@mtt.fi \\ Christian Eriksson
}

MTT Agrifood Research Finland, Data and Information Services, FIN-31600 Jokioinen, Finland

Mauri Räkköläinen

MTT Agrifood Research Finland, Laukaa Research and Elite Plant Station, FIN-41330 Vihtavuori, Finland

Martti Vuorinen

MTT Agrifood Research Finland, Häme Research Station, FIN-36600 Pälkäne, Finland

\begin{abstract}
Cover crops can be used to reduce leaching and erosion, introduce variability into crop rotation and fix nitrogen $(\mathrm{N})$ for use by the main crops. In Finland, undersowing is a suitable method for establishing cover crops in cereal cropping. The effect of annual undersowing on cereal grain yield and soil mineral N content in spring was studied at two sites. Red clover (Trifolium pratense L.), white clover (Trifolium repens L.), a mixture of red clover and meadow fescue (Festuca pratensis Huds.), and westerwold ryegrass (Lolium multiflorum Lam. var. westerwoldicum) were undersown in spring cereals in the same plots in six successive seasons, and their effects on cereal yield were estimated. Annual undersowing with clovers increased, and undersowing with westerwold ryegrass decreased cereal grain yields. The grain yield was only slightly lower with a mixture of red clover and meadow fescue than with red clover alone. Westerwold ryegrass did not affect soil mineral $\mathrm{N}$ content in spring and the increase attributable to clovers was small. The mixture of red clover and meadow fescue affected similarly to pure red clover. Soil fertility was not notably improved during six years of undersowing according to grain yield two years later.
\end{abstract}

Key words: spring cereals, clovers, cover crops, grasses, grain yield, intercropping, soil mineral nitrogen

\section{Introduction}

Growing cover crops after harvesting the main crop can reduce leaching and erosion during au- tumn and winter. Legumes can fix nitrogen $(\mathrm{N})$ to the benefit of other crops in the rotation. Undersowing also introduces diversity into crop rotations when the rotation of main crops remains unchanged. In areas with long growing 
Känkänen, H. et al. Effect of annual undersowing on cereal grain yields

seasons, cover crops can be sown after harvesting the main crop, but when the post-harvest period before winter is short, dry matter production is likely to be low (Vos 1992). Hence, undersowing in cereals is a suitable method for establishing a cover crop on northern latitudes (Jensen 1991, Alvenäs and Marstorp 1993).

Intercropping promotes competition (Gliessman 1986), and undersowing is a form of intercropping. The extent of competition depends on several things in cultivation technique, and is largely influenced by the undersown species (Trenbath 1976), which is studied here. Variability in growing conditions results in considerable variation in biomass production among sites and years. In addition to the competitive effect on the main crop, an undersown crop can affect the growth of the subsequent crop (Brandt et al. 1989). These two effects of undersowing have usually been studied separately, whereas the combined effect of annual undersowing has been studied less. Moreover, because of the obvious sensitivity of undersown crops to the weather (Nilsdotter-Linde et al. 1995), long-term experiments are needed to allow a more accurate understanding of the effects of undersowing.

The residual $\mathrm{N}$ effect of cover crop is affected by many factors, and soil mineral $\mathrm{N}$ content before the start of the growing season can tell only part of the effect on the subsequent crop. Net $\mathrm{N}$ mineralisation during the growing season is essential (Francis et al. 1994), affected by same factors as affecting the growth of the succeeding crop: soil type, fertility and structure, weather and cultivation practices. The release of $\mathrm{N}$ from plant material can take longer than one growing season (Jensen 1992). Differences in soil mineral $\mathrm{N}$, decomposition rate of incorporated plant material and competition in the crop are not easily separable when the effect of repetitive undersowing on grain yield is assessed. Furthermore, $\mathrm{N}$ fertilisation is implicated when the effect of plant biomass on the succeeding cereal grain yield is measured, for instance $\mathrm{Ba}$ daruddin and Meyer (1990) found both increasing, decreasing and insignificant effect of $\mathrm{N}$ fertilisation on grain yield after legumes.
Our aim was to investigate how annually repeated undersowing affects spring cereal grain yields and soil mineral $\mathrm{N}$ content at sowing under different $\mathrm{N}$ fertilizer regimes.

\section{Material and methods}

The experiments were established in 1991 at the Häme Research Station in Pälkäne $\left(61^{\circ} 20^{\prime} \mathrm{N}\right.$, $\left.24^{\circ} 13^{\prime} \mathrm{E}\right)$ and at the Laukaa Research and Elite Plant Station $\left(62^{\circ} 25^{\prime} \mathrm{N}, 26^{\circ} 15^{\prime} \mathrm{E}\right)$. The soils were classified at both ends of the trial areas according to the soil taxonomy (the names and the conventional abbreviations of the Finnish names of the soil types in top soil are given in parentheses). At Pälkäne the soil was Aquic Eutrocryept, fine (sandy loam, KHt) and Oxyaquic Cryopsamment (loamy sand, KHt) in the ends of field. At Laukaa the soil was Typic Cryaquept or Typic Cryaquent (silt loam, He) and Typic Cryaquent or Typic Cryaquept (silt loam, Hs), respectively (Yli-Halla et al. 2000).

The experiments were designed as split-plot trials with $\mathrm{N}$ rates as the main plot (size $6 \mathrm{~m} \times$ $20 \mathrm{~m}$ and $7.5 \mathrm{~m} \mathrm{x} 20 \mathrm{~m}$ at Pälkäne and Laukaa, respectively), arranged in a randomized complete block design with three replicate blocks. The split-plot treatments (five undersowings) were randomized among the subplots $(6 \mathrm{~m} \times 4 \mathrm{~m}$ and $7.5 \mathrm{~m} \times 4 \mathrm{~m}$ at Pälkäne and Laukaa, respectively) within each main plot.

Red clover (Trifolium pratense L.), white clover (Trifolium repens L.), mixture of red clover and meadow fescue (Festuca pratensis Huds.) (R.C. \& M.F.), and westerwold ryegrass (Lolium multiflorum Lam. var. westerwoldicum) were undersown in spring cereals in same plots in six successive seasons, 1991-1996. In one treatment (control) there was no undersowing. In 1997 and 1998, spring barley without undersowing was grown on all plots to measure the residual effect of long-term undersowing. The seed rate for red clover, white clover and westerwold ryegrass was 6,6 and $10 \mathrm{~kg} \mathrm{ha}^{-1}$ of viable seed, respec- 
Vol. 10 (2001): 197-208.

tively. In the mixture the seed rates for red clover and meadow fescue were 3 and $6 \mathrm{~kg} \mathrm{ha}^{-1}$, respectively.

The sowing was done when the soil moisture was appropriate for sowing of spring cereals, which fell between 17 and 31 May. The seedbed was prepared with an S-tine harrow to $4-5 \mathrm{~cm}$ and 3-4 cm depth at Pälkäne and Laukaa, respectively. Spring barley was sown in 1991 and 1994, spring wheat in 1992 and 1995 and oats in 1993 and 1996 using a combined drill adjusted to those depths. The seed rates for barley, wheat and oats were those normally used in Finland, $450,500-650$ and 500 seeds per $\mathrm{m}^{2}$, respective1y. Undersowing was done across the cereal rows to about $2 \mathrm{~cm}$ depth at Pälkäne and $1 \mathrm{~cm}$ at Laukaa using a combined drill at Pälkäne and an Oyjord experimental sower at Laukaa. Undersowing was done after cereal sowing in the same day or in the next day, except five days later in 1993 and four days later in 1995 at Pälkäne. The row distance of both cereals and undersown crops was $12,5 \mathrm{~cm}$. The plots that were not undersown remained undisturbed during this phase. The trial areas were rolled with a continental Cambridge roller before and after undersowing.

All cover crop treatments were combined with $\mathrm{N}$ treatments consisting of $\mathrm{N}$ rates of 0,30 , 60 or $90 \mathrm{~kg} \mathrm{~N} \mathrm{ha}^{-1}$. Fertiliser $\mathrm{N}$ was applied at a depth of 7-9 $\mathrm{cm}$ at the time of sowing, and the $\mathrm{N}$ level was unchanged in each plot in every year. Phosphorus and potassium were applied separately to the entire experimental area according to recommendations before sowing the cereal.

After harvesting the cereal crop in August or September, straw residues were collected from the trial area. The cereal crop was harvested leaving the stubble as high as possible, to ensure minimal damage to the undersown crop.

Soil was ploughed in late October in 19911996 to ensure a sufficiently long growing season for the undersown crops. In 1992 at Laukaa ploughing was not done until 7 December, after early snow cover had melted. In 1997 ploughing was done in late September/early October, the normal ploughing time in Finland.

Plant samples $\left(0.25 \mathrm{~m}^{2}\right.$ per plot $)$, including above ground material of the undersown crop, were taken at cereal harvest and before autumn ploughing. Plants were cut with scissors at the base. Root samples from the $0-25 \mathrm{~cm}$ soil layer were taken immediately before autumn ploughing. The root samples were taken manually with a steel box and a spade $(25 \mathrm{~cm} \times 25 \mathrm{~cm}$ surface area) during the first three years and mechanically with a tractor borer $(12.5 \mathrm{~cm} \times 12.5 \mathrm{~cm}$ surface area) in later years. Roots were washed manually in first three years and in later years with a hydropneumatic root washer (Smucker et al. 1982). Organic matter was separated with forceps. Shoot and root samples were dried in an oven $\left(2\right.$ hours at $105^{\circ} \mathrm{C}$ and overnight at $\left.60^{\circ} \mathrm{C}\right)$, and dry matter, nitrogen contents $(\%)$ and yields $\left(\mathrm{kg} \mathrm{ha}^{-1}\right)$ were measured. Measured above ground material included only biomass from undersown crops, but root biomass from other plants than cover crops was not sorted out from root samples. Shoot and root samples were taken in all undersowing years, except at Pälkäne in 1992 because of early snow cover and in 1993 because of almost total failure of cover crop establishment. $\mathrm{N}$ yields of undersown crops are presented here as background information. The samples from the separate replicates were mixed and statistical analysis was consequently not possible.

Soil samples were taken before sowing in 1992-1998 from the 0-30 cm soil layer. Soil from 16 cores was mixed. At Pälkäne however, samples from separate replicates were mixed in 1992, 1993 and 1995, and results from those years were not included in the statistical analysis. The soil samples were extracted with $2 \mathrm{M}$ $\mathrm{KCl}$. The nitrate $\left(\mathrm{NO}_{3}^{-}\right)$and ammonium $\left(\mathrm{NH}_{4}^{+}\right)$ $\mathrm{N}$ contents of the extracts were analysed with a scalar autoanalyser (air segmented flow analyser, photometric detection) and converted into mineral $\mathrm{N} \mathrm{kg} \mathrm{ha}{ }^{-1}$.

Cereal crops were harvested with a combine harvester (18 and 22,5 $\mathrm{m}^{2}$ per plot) when at growth stage 92 (Zadoks et al. 1974). After the cereals had been dried in an air stream $\left(+40^{\circ} \mathrm{C}\right)$ and sorted, grain yield was measured and calculated as $\mathrm{kg} \mathrm{ha}^{-1}$ at $15 \%$ grain moisture. 
Känkänen, H. et al. Effect of annual undersowing on cereal grain yields

Table 1. Mean air temperature $\left({ }^{\circ} \mathrm{C}\right)$, temperature sum $\left(\mathrm{dd}{ }^{\circ} \mathrm{C}\right.$ as $0{ }^{\circ} \mathrm{C}$ base temperature) and precipitation sum (mm) in periods between end of soil frost, sowing, harvest, ploughing and beginning of soil frost.

\begin{tabular}{|c|c|c|c|c|c|c|c|c|c|c|c|c|}
\hline \multirow[b]{2}{*}{ period $^{1)}$} & \multicolumn{4}{|c|}{ Mean air temperature } & \multicolumn{4}{|c|}{ Temperature sum } & \multicolumn{4}{|c|}{ Precipitation sum } \\
\hline & 1 & 2 & 3 & 4 & 1 & 2 & 3 & 4 & 1 & 2 & 3 & 4 \\
\hline \multicolumn{13}{|l|}{ Pälkäne } \\
\hline 1991 & & 15.0 & 9.1 & 4.8 & & 1544 & 245 & 269 & & 234 & 50 & 118 \\
\hline $1992^{2)}$ & 9.5 & 15.1 & 7.4 & - & 266 & 1722 & 199 & - & 8 & 302 & 82 & - \\
\hline $1993^{2)}$ & 15.2 & 12.1 & 4.9 & - & 122 & 1592 & 107 & - & 1 & 268 & 57 & - \\
\hline 1994 & 7.1 & 14.9 & 8.7 & 4.1 & 42 & 1461 & 487 & 49 & 4 & 155 & 178 & 30 \\
\hline $1995^{2)}$ & 9.5 & 15.0 & 8.1 & - & 43 & 1874 & 317 & - & 28 & 210 & 74 & - \\
\hline 1996 & 8.8 & 14.4 & 6.7 & 3.2 & 133 & 1529 & 316 & 106 & 19 & 172 & 69 & 130 \\
\hline 1997 & 8.7 & 16.3 & 8.0 & 3.3 & 122 & 1885 & 137 & 109 & 12 & 285 & 25 & 68 \\
\hline 1998 & 8.9 & 13.5 & & & 71 & 1563 & & & 7 & 300 & & \\
\hline \multicolumn{13}{|l|}{ Laukaa } \\
\hline 1991 & & 14.5 & 8.7 & 1.5 & & 1250 & 481 & 95 & & 247 & 118 & 79 \\
\hline $1992^{2)}$ & 7.6 & 14.0 & 1.9 & - & 166 & 1585 & 238 & - & 6 & 270 & 150 & - \\
\hline $1993^{2)}$ & 13.2 & 11.9 & 2.6 & - & 159 & 1385 & 138 & - & 7 & 230 & 60 & - \\
\hline 1994 & 5.8 & 15.4 & 7.0 & -1.6 & 111 & 1233 & 525 & 19 & 28 & 140 & 232 & 24 \\
\hline 1995 & 8.4 & 15.1 & 7.8 & 2.8 & 236 & 1461 & 350 & 47 & 59 & 172 & 114 & 11 \\
\hline 1996 & 7.8 & 13.7 & 5.4 & 0.8 & 155 & 1454 & 232 & 98 & 20 & 257 & 49 & 173 \\
\hline 1997 & 6.6 & 16.5 & 11.7 & -0.4 & 106 & 1300 & 537 & 72 & 28 & 111 & 117 & 93 \\
\hline 1998 & 9.8 & 12.8 & & & 137 & 1340 & & & 6 & 333 & & \\
\hline
\end{tabular}

1) Period 1 is end of soil frost - sowing, period 2 is sowing - harvest, period 3 is harvest - ploughing, period 4 is ploughing - beginning of soil frost

2) Ploughing was done after day of the beginning of soil frost

Temperature and precipitation sums were measured in four periods of each year when the soil remained unfrozen (Table 1). Rainfall distribution inside periods varied considerably. Early summer was very dry at both sites in 1992 and exceptionally rainy at Pälkäne in 1995. Early autumn, before and after cereal harvest, was dry in 1993 at Laukaa and in 1996 at both sites. The temperature sum $\left(>0^{\circ} \mathrm{C}\right)$ from harvest to ploughing was normally higher in years when barley was sown because of earlier harvest time. Ploughing was done after the first soil frosts in 1992 and 1993 at both sites, and in 1995 at Pälkäne.

The effect of undersowing on grain yield was studied in four periods: 1) the first year of undersowing, 2) additional years of undersowing (annual means were used in statistical analysis), 3 ) the first year after the last undersowing year, and 4) the second year after the last undersow- ing year. For studying the effect of undersowing on soil mineral $\mathrm{N}$ at the beginning of the growing season, periods 2, 3 and 4 were examined.

For analysis of grain yield the following mixed model was used:

$$
\begin{aligned}
Y_{i j k l m}= & \mu+S_{i}+b_{j(i)}+F_{k}+S F_{i k}+e_{i j k}+U_{l}+S U_{i l}+F U_{k l} \\
& +S F U_{i k l}+f_{i j k l}+P_{m}+S P_{i m}+g_{i j m}+F P_{k m} \\
& +S F P_{i k m}+h_{i j k m}+U P_{l m}+S U P_{i l m}+o_{i j l m} \\
& +F U P_{k l m}+S F U P_{i k l m}+s_{i j k l m}
\end{aligned}
$$

where $Y_{i j k l m}$ is the response for site $\mathrm{i}$, block $\mathrm{j}$, fertiliser rate $\mathrm{k}$, undersowing 1 and period $\mathrm{m} ; \mu$ is the overall mean; $b$ is the random block effect; $\mathrm{S}, \mathrm{F}, \mathrm{U}$ and $\mathrm{P}$ are the fixed effects of site, fertiliser, undersowing and period, respectively; SF, SU, FU, SP, FP and UP are the two-factor interactions of the fixed effects and SFU, SFP, SUP and FUP are the three-factor interaction and SFUP is the four-factor interaction; $e, f, g, h, o$ 
Vol. 10 (2001): 197-208.

and $s$ are the random error terms. The random variables $b_{j(i)}, e_{i j k}, f_{i j k l}, g_{i j m}, h_{i j k m}, o_{i j l m}$ and $s_{i j k l m}$ were assumed to be independent and normally distributed with zero means and constant variances. Furthermore, the error vectors $s_{i j k l}=\left(s_{i j k l 1}, s_{i j k l 2}\right.$, $\left.s_{i j k l 3}, s_{i j k l 4}\right)$ for grain yield were assumed to be independent and multivariate normal with zero means and unstructured covariance matrices $\Sigma$. The experiments were analysed separately when the response variable was soil mineral $\mathrm{N}$, because it had unequal dispersions at different sites. The model, distribution assumption and covariance structure were otherwise similar to that above except that terms related to the site were removed and there were three periods. The models were fitted by using the residual maximum likelihood (REML) estimation method. The degrees of freedom were approximated through the method of Kenward and Roger (1997). Graphical plots were used to check the fit of the data with the distributional assumptions of the models. The residuals were checked for normality using box plots (Tukey 1977). In addition, the residuals were plotted against the fitted values. In the analyses PROC MIXED (Littell et al. 1996) of the SAS/ STAT software was used.

For grain yield and mineral N planned comparisons between means were made using $95 \%$ confidence intervals $(95 \% \mathrm{CI})$. If the $95 \% \mathrm{CI}$ does not include zero the difference between means is statistically significant at the $5 \%$ level.

\section{Results}

\section{$\mathrm{N}$ yields of undersown crops}

The N yields were higher at Pälkäne than at Laukaa, especially for white clover and westerwold ryegrass. The $\mathrm{N}$ yield of red clover, white clover and R.C \& M.F. decreased, and that of westerwold ryegrass increased with increasing $\mathrm{N}$ fertilisation (Table 2). The above-ground biomass $\mathrm{N}$ content was on average $3-3.6 \%$ in red and

Table 2. Total $\mathrm{N}$ yield in shoots and roots of cover crops late in autumn after undersowing in spring cereals the previous spring, depending on $\mathrm{N}$ fertilisation. The yeilds are as an average of all six years with cover crops at Laukaa, and all years except 1992 and 1993 at Pälkäne.

\begin{tabular}{|c|c|c|c|c|c|}
\hline \multirow[t]{2}{*}{ crop } & \multirow[t]{2}{*}{$\begin{array}{l}\mathrm{N} \text { fertil. } \\
\mathrm{kg} \mathrm{ha}^{-1}\end{array}$} & \multicolumn{2}{|c|}{$\begin{array}{c}\text { Pälkäne } \\
\mathrm{N} \text { yield, kg ha }{ }^{-1}\end{array}$} & \multicolumn{2}{|c|}{$\begin{array}{c}\text { Laukaa } \\
\mathrm{N} \text { yield, } \mathrm{kg} \mathrm{ha}^{-1} \\
\end{array}$} \\
\hline & & shoots & roots & shoots & roots \\
\hline \multirow[t]{4}{*}{ red clover } & 0 & 30 & 41 & 29 & 36 \\
\hline & 30 & 18 & 25 & 25 & 33 \\
\hline & 60 & 19 & 21 & 18 & 22 \\
\hline & 90 & 16 & 21 & 13 & 16 \\
\hline \multirow[t]{4}{*}{ white clover } & 0 & 56 & 43 & 44 & 15 \\
\hline & 30 & 46 & 33 & 30 & 11 \\
\hline & 60 & 50 & 25 & 23 & 8 \\
\hline & 90 & 43 & 30 & 20 & 10 \\
\hline \multirow[t]{4}{*}{ red clover } & 0 & 19 & 41 & 25 & 27 \\
\hline & 30 & 17 & 17 & 20 & 23 \\
\hline & 60 & 21 & 27 & 13 & 12 \\
\hline & 90 & 9 & 20 & 11 & 15 \\
\hline \multirow[t]{4}{*}{ westerwold ryegrass } & 0 & 16 & 15 & 6 & 3 \\
\hline & 30 & 24 & 18 & 6 & 2 \\
\hline & 60 & 30 & 18 & 8 & 2 \\
\hline & 90 & 30 & 23 & 9 & 5 \\
\hline
\end{tabular}


Känkänen, H. et al. Effect of annual undersowing on cereal grain yields

white clover, $2.8-3 \%$ in R.C. \& M.F. and 1.8$2.5 \%$ in westerwold ryegrass. The root $\mathrm{N}$ content was on average $1.7-2.8 \%$ in red and white clover, $1.3-2.7 \%$ in R.C. \& M.F. and $0.9-1.1 \%$ in westerwold ryegrass, the values being somewhat higher at Laukaa than Pälkäne.

Growth of undersown crops varied among years and sites. In 1993 at Laukaa the $\mathrm{N}$ yields were only $3-5 \mathrm{~kg} \mathrm{ha}^{-1}$ before autumn ploughing, when high rates of $\mathrm{N}$ fertiliser application were used on red clover, white clover and R.C. \& M.F., and when low $\mathrm{N}$ fertilisation was used on westerwold ryegrass. The highest $\mathrm{N}$ yields were recorded at Pälkäne in $1995,160 \mathrm{~kg} \mathrm{ha}^{-1}$ in white clover with $0 \mathrm{~N}$ and $115 \mathrm{~kg} \mathrm{ha}^{-1}$ in westerwold ryegrass with $90 \mathrm{~N}$.

\section{Grain yields}

There was a statistically significant interaction between undersown crop and period $\left(\mathrm{F}_{12,44.5}=\right.$ $3.59, \mathrm{P}<0.001)$. Although the grain yield levels were often substantially different between the two sites, the effect of the undersown crop was usually similar. In general, $\mathrm{N}$ fertilisation did not influence the effect of an undersown crop, although in period 2 there was some evidence of differences.

\section{Grain yields in different periods}

In period 1, the estimated grain yield without undersowing was $2840 \mathrm{~kg} \mathrm{ha}^{-1}$ (standard error of means, SEM: $150 \mathrm{~kg} \mathrm{ha}^{-1}$ ). Undersowing did not have a statistically significant effect on grain yield of spring barley, not even in westerwold ryegrass, where the estimated mean yield was $207 \mathrm{~kg} \mathrm{ha}^{-1}$ (95\% CI from -64 to $479 \mathrm{~kg} \mathrm{ha}^{-1}$ ) lower than without undersowing (Fig. 1).

In period 2, the estimated grain yield without undersowing was $3140 \mathrm{~kg} \mathrm{ha}^{-1}$ (SEM: 134 $\left.\mathrm{kg} \mathrm{ha}^{-1}\right)$. Undersown clovers increased, and ryegrass decreased, the average cereal grain yield as compared with no undersowing. The increase in grain yield was $290 \mathrm{~kg} \mathrm{ha}^{-1}(95 \% \mathrm{CI}$, from 100 to $\left.477 \mathrm{~kg} \mathrm{ha}^{-1}\right), 280 \mathrm{~kg} \mathrm{ha}^{-1}(95 \% \mathrm{CI}$ from 86 to $\left.464 \mathrm{~kg} \mathrm{ha}^{-1}\right)$, and $250 \mathrm{~kg} \mathrm{ha}^{-1}$ (95\% CI from 60 to $438 \mathrm{~kg} \mathrm{ha}^{-1}$ ) in red clover, white clover and R.C. \& M.F., respectively. The decrease in westerwold ryegrass was $230 \mathrm{~kg} \mathrm{ha}^{-1}$ (95\% CI from 42 to $420 \mathrm{~kg} \mathrm{ha}^{-1}$ ). There was no statistically significant interaction between the experimental site, crop, $\mathrm{N}$ fertilisation and period $\left(\mathrm{F}_{36,94.5}=1.26, \mathrm{P}=0.189\right)$. However, at Laukaa there were practically significant differences between the effect of leguminous crops with different $\mathrm{N}$ fertilisations. The increase of the grain yield in red clover, white clover and R.C.

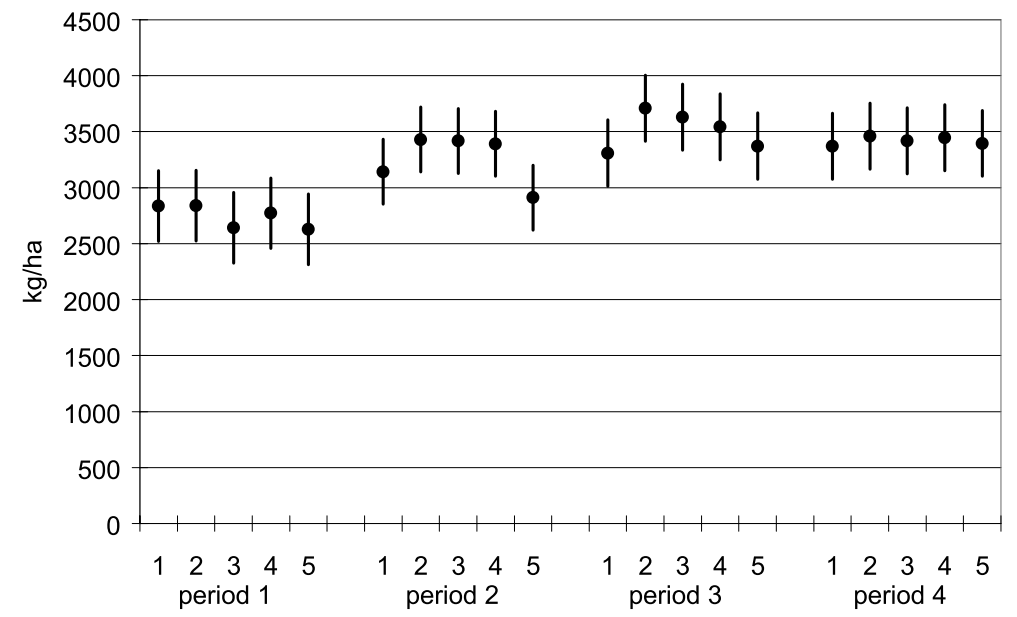

Fig. 1. Estimated mean grain yield (kg ha ${ }^{-1}$, all $\mathrm{N}$ levels) of cereals and $95 \%$ confidence intervals without undersowing (1) and with undersowing of red clover (2), white clover (3), mixture of red clover and meadow fescue (4), and westerwold ryegrass (5). Period $1=$ the first year of undersowing, period $2=$ additional five years of undersowing, period $3=$ the first year after the last undersowing year, period $4=$ the second year after the last undersowing year. 
Vol. 10 (2001): 197-208.

\& M.F. as an average was $710,460,330$ and $250 \mathrm{~kg} \mathrm{ha}^{-1}$ at $0 \mathrm{~N}, 30 \mathrm{~N}, 60 \mathrm{~N}$ and $90 \mathrm{~N}$, respectively.

In period 3 the estimated grain yield of spring barley in crop 1 was $3310 \mathrm{~kg} \mathrm{ha}^{-1}$ (SEM: $138 \mathrm{~kg}$ $\left.\mathrm{ha}^{-1}\right)$. Undersown clovers increased the average cereal grain yield as compared with no undersowing in preceding years. The increase in grain yield was $400 \mathrm{~kg} \mathrm{ha}^{-1}$ (95\% CI from 190 to 609), $320 \mathrm{~kg} \mathrm{ha}^{-1}$ (95\% CI from 111 to 530), and 230 $\mathrm{kg} \mathrm{ha}^{-1}$ (95\% CI from 25 to 444) in crops 2, 3 and 4 , respectively. The estimated yield in crop $5\left(3370 \mathrm{~kg} \mathrm{ha}^{-1}\right)$ was similar to that in crop 1 .

In period 4 , the estimated grain yield in crop 1 was $3370 \mathrm{~kg} \mathrm{ha}^{-1}$ (SEM: $137 \mathrm{~kg} \mathrm{ha}^{-1}$ ). The estimated grain yield of spring barley in other crops (3400-3460 $\mathrm{kg} \mathrm{ha}^{-1}$ ) did not differ statistically significantly or practically from that of crop 1 .

\section{Mineral N}

At Pälkäne, the mineral $\mathrm{N}$ content at sowing in spring was similar in all undersowing treatments $\left(\mathrm{F}_{4,24.3}=1.83, \mathrm{P}=0.156\right)$, and there was no significant interaction between undersown crop and period $\left(\mathrm{F}_{8,23.2}=1.76, \mathrm{P}=0.136\right)$. However, only results from years 1994 and 1996 were included in the statistical analysis, because samples from separate replicates were mixed in other years. According to all sampled years, white clover showed a tendency to increased mineral $\mathrm{N}$ content in 1995 and 1996.

At Laukaa there was a statistically significant interaction between $\mathrm{N}$ fertilisation, crop and period $\left(\mathrm{F}_{24,26.2}=2.49, \mathrm{P}=0.012\right)$. In period 2 (data from 4 years) undersowing had an effect on soil mineral $\mathrm{N}$ at all $\mathrm{N}$ fertilisation levels. $\mathrm{N}$ fertilisation had no effect on soil mineral $\mathrm{N}$ (about $16 \mathrm{~kg} \mathrm{ha}^{-1}$ ) when no undersowing was done. However, the effects of different undersown crops differed among $\mathrm{N}$ fertilisation levels (Fig. 2). At $0 \mathrm{~N}$, red clover, white clover and R.C. \& M.F. increased the average mineral N content as compared with no undersowing. At $30 \mathrm{~N}$ and $60 \mathrm{~N}$, red and white clover, and at $90 \mathrm{~N}$, white clover increased the average mineral $\mathrm{N}$ content as compared with no undersowing.

In period 3, white clover at $0 \mathrm{~N}$ fertiliser level was the only cover crop that increased the content of mineral $\mathrm{N}$ in the soil (Fig. 2).

In period 4 the effects of undersown crops varied among $\mathrm{N}$ rates 0,30 and $60 \mathrm{~N}$ (Fig. 2). The mineral $\mathrm{N}$ content in the soil after Westerwold ryegrass was lower at $0 \mathrm{~N}$, but higher at $60 \mathrm{~N}$ as compared with no undersowing. The mineral $\mathrm{N}$ content after white clover at $30 \mathrm{~N}$ was lower, and after R.C. \& M.F. at $60 \mathrm{~N}$ higher than after no undersowing.

\section{Discussion}

Because of the short post-harvest period before winter, cover crops can be established successfully in cereal cropping in Finland only by undersowing. If sown after a main crop, an air temperature sum $\left(>0^{\circ} \mathrm{C}\right)$ of 500 is considered necessary for sufficient cover crop establishment and growth (Schröder et al. 2001). During the experiments presented in this paper, this sum was reached between harvest and ploughing only once, and in some years the sum was only a little above 100. While enabling establishment of a reasonable cover crop in autumn, undersowing caused competition during growth of the main crop as earlier reported by Kvist (1992) and Beck-Friis et al. (1993). However, when used repeatedly, the residual effects and competition caused by undersown crops are confounded.

The cover crop yields were small in years with little precipitation in early summer or early autumn or with low temperatures between harvest and ploughing. This is in agreement with Kunelius et al. (1992), Nilsdotter-Linde et al. (1995), Ohlander and Bergkvist (1995), Ohlsson (1995) and Schröder et al. (1997). A long-term experiment such as reported here provides results over an extended period and allows interpretation of the effects of regular undersowing in crop rotation. 
Känkänen, H. et al. Effect of annual undersowing on cereal grain yields

ON

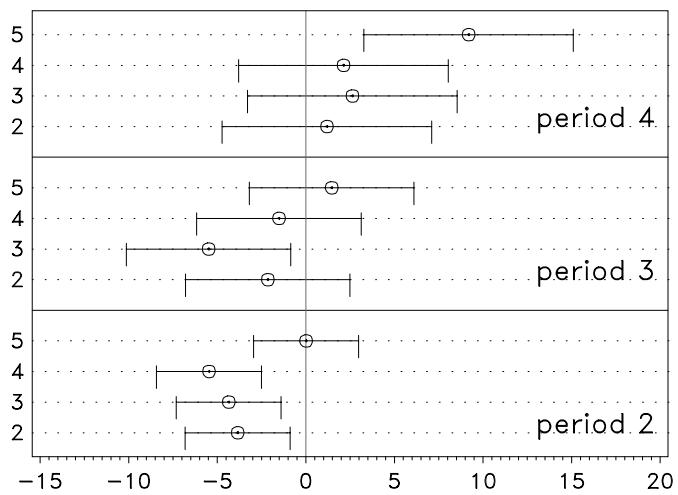

$60 N$

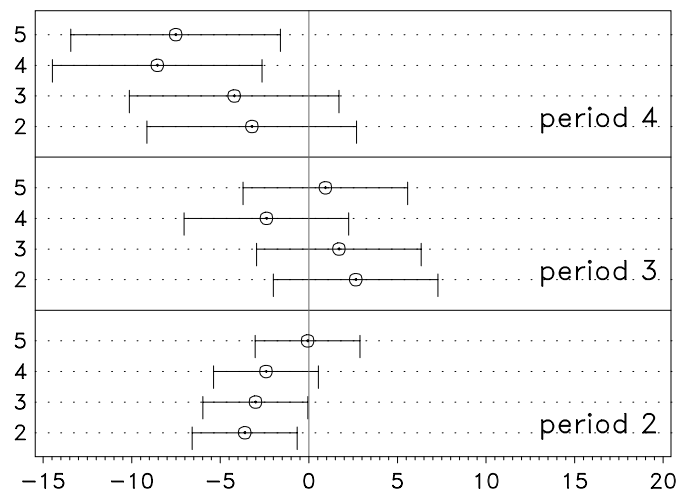

$30 \mathrm{~N}$

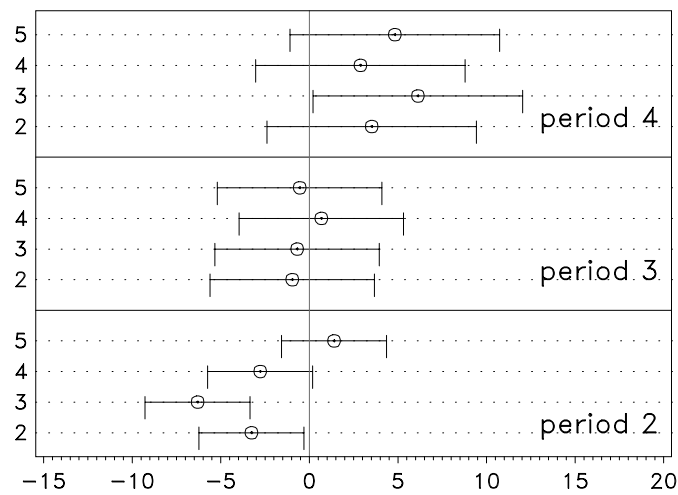

$90 \mathrm{~N}$

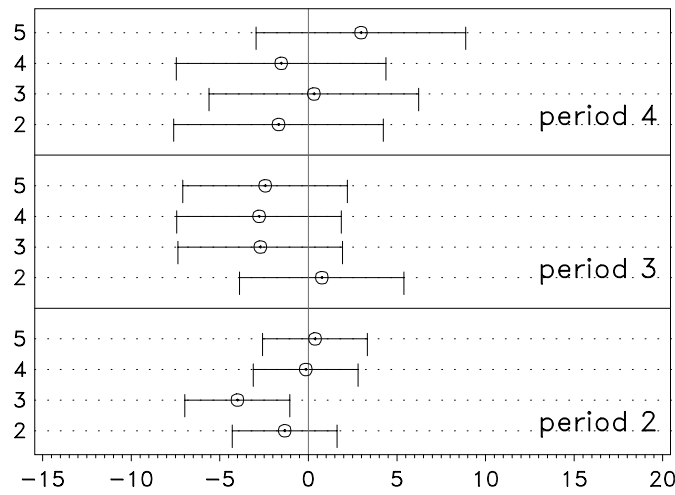

Fig. 2. The differences and $95 \%$ confidence intervals between estimated means of soil mineral $\mathrm{N}\left(0-30 \mathrm{~cm}, \mathrm{~kg} \mathrm{ha}^{-1}\right)$ in spring at sowing at Laukaa, when undersowing with different crops (2-5) are compared with cereal cropping without undersowing. The 0 point corresponds the amount of $\min \mathrm{N}$ without undersowing in each period, and negative value means that this amount is smaller than the compared one. Undersown crop $2=$ red clover, $3=$ white clover, $4=$ mixture of red clover and meadow fescue, and $5=$ westerwold ryegrass. Period $2=$ additional five years of undersowing after the first year, period $3=$ the first year after the last undersowing year, period $4=$ the second year after the last undersowing year.

Westerwold ryegrass tended to decrease the grain yield of spring barley during the first year of the experiment, although limited data contributed to weak statistical significance. The grain yield decrease was about the same as was considered in advance to be a practically significant difference, that is $200 \mathrm{~kg} \mathrm{ha}^{-1}$. The other undersown crops did not notably affect the grain yield in the first year. Competition between species is however obvious, as reported by Gliessman (1986). Kunelius et al. (1992) reported that red clover decreased grain yield of barley, but ryegrass reduced the grain yield much more. Contrastingly, Nilsdotter-Linde et al. (1995) reported that undersown grasses did not cause any significant reduction in spring barley grain yield. Undersown legumes have been reported to both decrease (Brandt et al. 1989) and increase (Hartl 1989) the yield of main crops, but no effects were found here in the first year of the experiment. Kauppila (1983), Dachler and Kochl (1994) and Ghaffarzadeh (1997) reported minor effects on 
Vol. 10 (2001): 197-208.

cereal grain yield in the undersowing year irrespective of undersown crop species.

During the following five years of the experiment (period 2), not only competition, but also effects caused by previous cover crop were expected. Such effects have been reported to be positive after legumes (Kauppila 1983, Brandt et al. 1989, Dachler and Kochl 1994, Ghaffarzadeh 1997) and negative, negligible or positive after grasses (Känkänen et al. 1999). Although competition effects and residual effects were confounded here, the yield decreasing effect of ryegrass was similar in this period to that in the first year. Moreover, Beck-Friis et al. (1993) found that repeated undersowing of Italian ryegrass decreased cereal grain yields by $5 \%$ compared with no undersowing. In contrast to the results reported here, they also found that red clover caused a decrease in the yield of the main crop in some years. We established a positive effect of legumes, also when repeatedly undersown. In other words, the positive residual effect was greater than the negative competition effect caused by clovers, which is in accordance with the negligible effect on grain yield found for the first year of experimentation. The grain yields were similar in a mixture of meadow fescue and red clover as in a pure stand of red clover. This was to some extent anticipated, because our mixture was clover-dominated.

The effect of an undersown crop on the grain yield was similar irrespective of $\mathrm{N}$ fertilisation of the main crop. However, there were signs of a more substantial effect at $0 \mathrm{~N}$ when clovers were undersown, obviously because of higher amount of fixed N. Further, according to Badaruddin and Meyer (1990) and Lindén and Wallgren (1993), the positive effect of $\mathrm{N}$ rich plant biomass is often reduced with increasing $\mathrm{N}$ application to the subsequent crop. Borresen (1994) reported Italian ryegrass to have negative after effect at low $\mathrm{N}$ application and positive at high $\mathrm{N}$ application. We found, however, no differences in the effect of westerwold ryegrass at different $\mathrm{N}$ rates, in spite of the fact that the yield of the ryegrass increased with increasing $\mathrm{N}$ fertilisation. Obviously both the ryegrass and the cereal benefit from $\mathrm{N}$ fertilisation, resulting in similar relative competition between the two species at different $\mathrm{N}$ rates.

The yield increasing effect of legumes was clearly seen following six-years of undersowing, but no long-term effects were established according to grain yields in the second year after undersowing. It appears that the effect of undersown clovers was only to contribute N; no other positive effects on soil fertility were observed. Borresen (1994) found undersown crops to increase the soil aggregate stability, but at the particular sites of our study soil fertility could have been adequate so that small amounts of biomass did not have clear positive effects. However, this was measured using grain yields and not by taking detailed soil nutrient and structure data. Correspondingly no negative cumulative effects following undersowing was found, either.

The residual effect of undersowing westerwold ryegrass on crop yields was negligible in both successive years. This suggests that $\mathrm{N}$ yield and content of ryegrass was too low for a positive effect on successive grain yield to be recorded, but was high enough to avoid yield decrease through immobilisation, which was reported in connection with decomposition of low $\mathrm{N}$ plant residues by Christensen (1986) and Mary et al. (1996). Schröder et al. (1997) found that the higher $\mathrm{N}$ content of Italian ryegrass following $\mathrm{N}$ fertilisation resulted in higher successive crop yields, whereas unfertilised ryegrass had no significant effects. Westerwold ryegrass did not cause pre-emptive competition, although Thorup-Christensen (1996) reported that late incorporation could lead to $\mathrm{N}$ assimilation by cover crop from a pool which might otherwise be available for the subsequent crop. This suggests that the grain yield decrease in years with undersowing occurred merely as a result of competition during the growth of the cereal crop. However, it was not possible to separate the positive and negative effects that could have occurred in the year of undersowing and successive years.

Similarly to (Wallgren and Lindén 1991, Goffart et al. 1992, Breland 1994), who found 
Känkänen, H. et al. Effect of annual undersowing on cereal grain yields

an increase in the soil mineral $\mathrm{N}$ content after legumes, soil mineral $\mathrm{N}$ content at sowing tended to be larger when clovers were undersown, especially when it was white clover and $\mathrm{N}$ fertiliser application rate was low. However, normally the increase was less than $5 \mathrm{~kg} \mathrm{ha}^{-1}$, which was considered as a practically significant difference. One reason for the small differences might be that samples were taken from the 0 $30 \mathrm{~cm}$ soil layer only, especially considering that soil at Pälkäne is vulnerable to leaching. Mineral $\mathrm{N}$ may have leached to deeper soil layers, similarly to Thorup-Kristensen (1997), who found that part of the $\mathrm{N}$ mineralised from a catch crop was assimilated by succeeding plants from much deeper soil layers than sampled here. However, late autumn ploughing is even a more probable reason for low min N, as Känkänen et al. (1998) found that delaying incorporation from early September to late October of N-rich plant material effectively decreased the mineralisation rate and leaching risk in Finnish conditions. In this study the mean air temperature in the period between ploughing and soil frost was near $0^{\circ} \mathrm{C}$, and ploughing was often done after the first soil frost. Accordingly, mineral $\mathrm{N}$ content in spring only partly explained the grain yield increase, and $\mathrm{N}$ mineralisation during summer undoubtedly had an impact, similarly to Francis et al. (1994).

There were similar amounts of $\min \mathrm{N}$ in a mixture of meadow fescue and red clover as in a pure stand of red clover. Apparently, our mixture was too clover-dominated to cause lower soil mineral $\mathrm{N}$ contents due to the grass component, like it did in study of Kuo and Sainju (1998) on leguminous - non-leguminous mixtures. Furthermore, mineral $\mathrm{N}$ levels were similar with westerwold ryegrass as without undersowing. However, westerwold ryegrass evidently was not an ideal catch crop, because the regrowth after cereal harvest was often poor. Italian ryegrass has been shown to accumulate more $\mathrm{N}$ after harvest of the cereal than westerwold ryegrass (Känkänen 2001).

\section{Conclusions}

The results suggest that annually repeated undersowing with nitrogen-fixing clovers is increasing cereal grain yields, because the positive residual effect is greater than the negative competition effect caused by clovers. If a cover crop is established by sowing westerwold ryegrass under a spring cereal, competition is decreasing grain yield of the cereal. When late autumn ploughing is used in connection with undersowing, the mineralisation of $\mathrm{N}$ from the undersown crop seems to be in balance with the needs of cereals in Finnish conditions. However, a more effective catch crop than westerwold ryegrass with vigorous growth in autumn should be evaluated for its suitability for repeated undersowing. If meadow fescue is used in a mixture with red clover, the effect of the undersown crop is more similar to the effect of legumes than that of grasses, as far as grain yield and soil mineral $\mathrm{N}$ content at sowing in spring are concerned.

\section{References}

Alvenäs, G. \& Marstorp, H. 1993. Effect of a ryegrass catch crop on soil inorganic-N content and simulated nitrate leaching. Swedish Journal of Agricultural Research 23: 3-14.

Badaruddin, M. \& Meyer, D.W. 1990. Green-manure legume effects on soil nitrogen, grain yield, and nitrogen nutrition of wheat. Crop Science 30: 819-825.

Beck-Friis, B., Lindén, B. \& Marstorp, H. 1993. Nitrogen in crops and soil in cultivation systems with autumn or spring ploughing and with and without catch crops. Soil Tillage and Environment. Proceedings of NJF seminar no. 228. Jokioinen, Finland, 8-10 June 1993. p. 133-144.

Borresen, T. 1994. Ryegrass and white clover undersown in small grains at three nitrogen levels and four tillage treatments: after-effects on grain yields and soil 
Vol. 10 (2001): 197-208.

structure. The use of catch or cover crops to reduce leaching and erosion. Proceedings of NJF seminar no. 245. Knivsta, Sweden, 3-4 October 1994. p. 148158.

Brandt, J.E., Hons F.M. \& Haby, V.A. 1989. Effects of subterranean clover interseeding on grain yield, yield components, and nitrogen content of soft red winter wheat. Journal of Production Agriculture 2: 347-351.

Breland, T.A. 1994. Measured and predicted mineralization of clover green manure at low temperatures at different depths in two soils. Plant and Soil 166: 1320.

Christensen, B.T. 1986. Barley straw decomposition under field conditions: effect of placement and initial nitrogen content on weight loss and nitrogen dynamics. Soil Biology \& Biochemistry 18: 523-529.

Dachler, M. \& Kochl, A. 1994. Effects of different species as green manures on yield and net profits of the subsequent crops. Bodenkultur 45: 139-146.

Francis, G.S., Haynes, R.J. \& Williams, P.H. 1994. Nitrogen mineralization, nitrate leaching and crop growth after ploughing-in leguminous and non-leguminous grain crop residues. Journal of Agricultural Science 123: 81-87.

Ghaffarzadeh, M. 1997. Economic and biological benefits of intercropping berseem clover with oat in cornsoybean-oat rotations. Journal of Production Agriculture 10: 314-319.

Gliessman, S.R. 1986. Plant interactions in multiple cropping system. In: Francis, C.A. (ed.). Multiple cropping systems. New York: Macmillan Publishing Company. p. 82-95. ISBN 0-02-948610-6.

Goffart, J.P., Ninane, V. \& Guiot, J. 1992. Green manures and nitrate leaching in winter in the loam region of Belgium. In: Francois, E. et al. (eds.). Nitrogen Cycling and Leaching in Cool and Wet Regions of Europe. COST 814 workshop, Gembloux, Belgium, October 22-23, 1992. p. 132-133.

Hartl, W. 1989. Influence of undersown clovers and weeds on the yield of winter wheat in organic farming. Agriculture, Ecosystems and Environment 27: 389-396.

Jensen, E.S. 1991. Nitrogen accumulation and residual effects of nitrogen catch crops. Acta Agriculturae Scandinavica 41: 333-344.

- 1992 . The release and fate of nitrogen from catchcrop materials decomposing under field conditions. Journal of Soil Science 43: 335-345.

Känkänen, H. 2001. Viherkesannot ja aluskasvit viljanviljelyssä. (Green manures and undersown crops in cereal crop rotation). MTT:n julkaisuja. Sarja B 25. 41 p. (in Finnish).

-, Kangas, A., Mela, T., Nikunen, U., Tuuri, H. \& Vuorinen, M. 1998. Timing incorporation of different green manure crops to minimize the risk of nitrogen leaching. Agricultural and Food Science in Finland 7: 553567.

-, Kangas, A., Mela, T., Nikunen, U., Tuuri, H. \& Vuorinen, M. 1999. The effect of incorporation time of different crops on the residual effect on spring cereals. Agricultural and Food Science in Finland 8: 285-298.

Kauppila, R. 1983. Palkokasvien käyttö viherlannoituksessa. (Use of legumes in green manuring.) In: Palko- kasvit viljelykierrossa ja -seoksissa. Biologisen typensidonnan ja ravinnetypen hyväksikäytön projekti. Helsinki: SITRA. Julkaisu 6: 51-92.

Kenward, M.G. \& Roger, J.H. 1997. Small sample inference for fixed effects from restricted maximum likelihood. Biometrics 53: 983-997.

Kunelius, H.T., Johnston, H.W. \& MacLeod, J.A. 1992. Effect of undersowing barley with Italian ryegrass or red clover on yield, crop composition and root biomass. Agriculture, Ecosystems and Environment 38: 127-137.

Kuo, S. \& Sainju, U.M. 1998. Nitrogen mineralization and availability of mixed leguminous and non-leguminous cover crop residues in soil. Biology and Fertility of Soils 26: 346-353.

Kvist, M. 1992. Catch crops undersown in spring barley. Competitive effects and cropping methods. In: Swedish university of agricultural sciences. Department of crop production science. Crop Production Science 15. $210 \mathrm{p}$.

Lindén, B. \& Wallgren, B. 1993. Nitrogen mineralization after leys ploughed in early or late autumn. Swedish Journal of Agricultural Research 23: 77-89.

Littell, R.C., Milliken, G.A., Stroup, W.W. \& Wolfinger, R.D. 1996. SAS System for Mixed Models. Cary, NC, USA: SAS Institute Inc. 633 p.

Mary, B., Recous, S., Darwis, D. \& Robin, D. 1996. Interactions between decomposition of plant residues and nitrogen cycling in soil. Plant and Soil 181: 71-82.

Nilsdotter-Linde, N., Bergkvist, G. \& Ohlander, L. 1995. Species and varieties of undersown catch crops in spring barley. The use of catch or cover crops to reduce leaching and erosion. Proceedings of NJF seminar no. 245. Knivsta, Sweden, 3-4 October 1994. p. 236-241.

Ohlander, L. \& Bergkvist, G. 1995. Effects of undersown catch crops in a four-year cereal/oil seed rotation with different soil management systems. The use of catch or cover crops to reduce leaching and erosion. Proceedings of NJF seminar no. 245. Knivsta, Sweden, 3-4 October 1994, p. 169-180.

Schröder, J.J. 2001. Reduction of nitrate leaching. The role of cover crops. Brochure of EU Concerted Action (AIR3) 2108. $6 \mathrm{p}$.

-, Ten Holte, L. \& Janssen, B.H. 1997. Non-overwintering cover crops: a significant source of N. Netherlands Journal of Agricultural Science 45: 231-248.

Smucker, A.J.M., Mc Burney, S.L. \& Srivastava, A.K. 1982. Quantitative separation of roots from compacted soil profiles by the hydropneumatic elutriation system. Agronomy Journal 74: 500-503.

Thorup-Kristensen, K. 1996. Effect of catch crop incorporation time on $\mathrm{N}$ availability for a succeeding crop. In: Schröder, J.J. (ed.). Long Term Reduction of Nitrate Leaching by Cover Crops. First Progress Report of EU Concerted Action (AIR3) 2108. p. 49-54.

- 1997. Root growth of nitrogen catch crops. In: Schröder, J.J. (ed.). Long Term Reduction of Nitrate Leaching by Cover Crops. Second Progress Report of EU Concerted Action (AIR3) 2108. p. 147-153.

Trenbath, B.R. 1976. Plant interactions in mixed crop communities. In: Papendic, R.I. et al. (eds.). American 
Känkänen, H. et al. Effect of annual undersowing on cereal grain yields

Society of Agronomy special publication 27: 129-169. ISBN 0-89118-045-1.

Tukey, J.W. 1977. Exploratory Data Analysis. Reading, MA : Addison-Wesley. $688 \mathrm{p}$.

Vos, J. 1992. Growth and nitrogen accumulation of catch crops. In: Francois, E. et al. (eds.). Nitrogen Cycling and Leaching in Cool and Wet Regions of Europe. COST 814 workshop, Gembloux, Belgium, October 22-23, 1992, p. 103-109.

Wallgren, B. \& Lindén, B. 1991. Residual nitrogen effects of green manure crops and fallow. Swedish Journal of Agricultural Research 21: 67-77.

Yli-Halla, M., Mokma, D.L., Peltovuori, T. \& Sippola, J. 2000. Suomalaisia maaprofiileja. Abstract: Agricultural soil profiles in Finland and their classification. Publications of Agricultural Research Centre of Finland. Serie A 78. 104 p.

Zadoks, J.C., Chang, T.T. \& Konzak, C.F. 1974. A decimal code for the growth stages of cereals. Weed Research 14: 415-421.

\title{
SELOSTUS
}

\section{Aluskasveja voi käyttääa toistuvasti viljan viljelyssä}

\author{
Hannu Känkänen, Christian Eriksson, Mauri Räkköläinen ja Martti Vuorinen \\ MTT (Maa- ja elintarviketalouden tutkimuskeskus)
}

Sadonkorjuun jälkeistä typen huuhtoutumista voidaan estää keräämällä typpeä tarkoitusta varten kylvettyjen kasvien avulla. Suomen kasvukausi ei ole riittävän pitkä maan vapaata typpeä keräävän kasvuston perustamiseen viljan puinnin jälkeen, vaan on käytettävä aluskasveja. Ihanteellinen aluskasvi kilpailee heikosti viljaa vastaan, mutta kasvaa voimakkaasti viljan puinnin jälkeen. Apilat aluskasveina tuottavat typpeä viljelykiertoon.

Tutkimuksessa selvitettiin, miten toistuva aluskasvien käyttö vaikuttaa viljojen jyväsatoon ja mineraalitypen määrään maassa kylvöaikaan. Kun aluskasveja viljellään vuosittain samalla paikalla, viljan satoon vaikuttavat samanaikaisesti kasvilajien välinen kilpailu kasvustossa ja edellisen vuoden aluskasvi esikasvina. Viljelyn monipuolistaminen aluskasvien avulla voi pidemmällä aikavälillä myös parantaa maan kasvukuntoa ja siten lisätä viljasatoa.

MTT:n Laukaan ja Pälkäneen tutkimusasemilla viljeltiin puna-apilaa, valkoapilaa, puna-apilan ja nurminadan seosta sekä westerwoldin raiheinää kuusi vuotta toistuvasti kevätviljan aluskasvina. Apilat lisäsivät viljan jyväsatoa keskimäärin $250-400 \mathrm{~kg} \mathrm{ha}^{-1}$ toisesta koevuodesta lähtien. Edellisen vuoden api- lasta vapautui typpeä viljan käyttöön, eikä kasvava apila kilpaillut voimakkaasti viljaa vastaan. Westerwoldinraiheinän aiheuttama kilpailu pienensi viljan jyväsatoa yli $200 \mathrm{~kg} \mathrm{ha}^{-1}$. Nurminadan merkitys punaapilan yhteydessä oli pieni, sillä seos oli apilavaltainen. Viimeisen vuoden jyväsatojen perusteella aluskasvien viljely ei oleellisesti parantanut koekenttien kasvukuntoa.

Aluskasvien käyttöön liittyvä myöhäinen syyskyntö ilmeisesti edesauttoi aluskasvien typen vapautumista sopivaan aikaan. Apiloiden toistuva viljely aluskasveina onkin hyvin Suomen oloihin sopiva menetelmä. Heiniäkin voidaan viljellä toistuvasti aluskasveina maan kasvipeitteisyyden lisäämiseksi ja ravinteiden keräämiseksi. Westerwoldinraiheinän sijaan tulisi kuitenkin käyttää lajeja, jotka kilpailevat vähemmän viljan kanssa ja kasvavat voimakkaammin syksyllä. Tällaisten lajien toistuvan käytön merkitystä maan ja viljojen typpitalouteen tulisi tutkia. Typpilannoituksen määrällä ei ollut suurta merkitystä aluskasvien vaikutuksen kannalta. Apiloiden vaikutus jyväsatoon ja maan mineraalitypen määrään näytti kuitenkin usein olevan voimakkain kun lannoitetyppeä ei annettu. 